\title{
Book Review of The Language Management Approach: A Focus on Research Methodology
}

Jingzhen Liu 刘景珍 ${ }^{1}$; Manchun Dai 戴曼纯 ${ }^{2}$

Received: December 24, 2019 / Accepted: April 3, 2020

The Language Management Approach: A Focus on Research Methodology

Lisa Fairbrother, Jiří Nekvapil and Marián Sloboda (eds.).

Berlin, Bern, Bruxelles, New York, Oxford, Warszawa,Wien: Peter Lang, 2018

ISBN 978-3-631-65042-4.

https://www.peterlang.com/view/title/16980

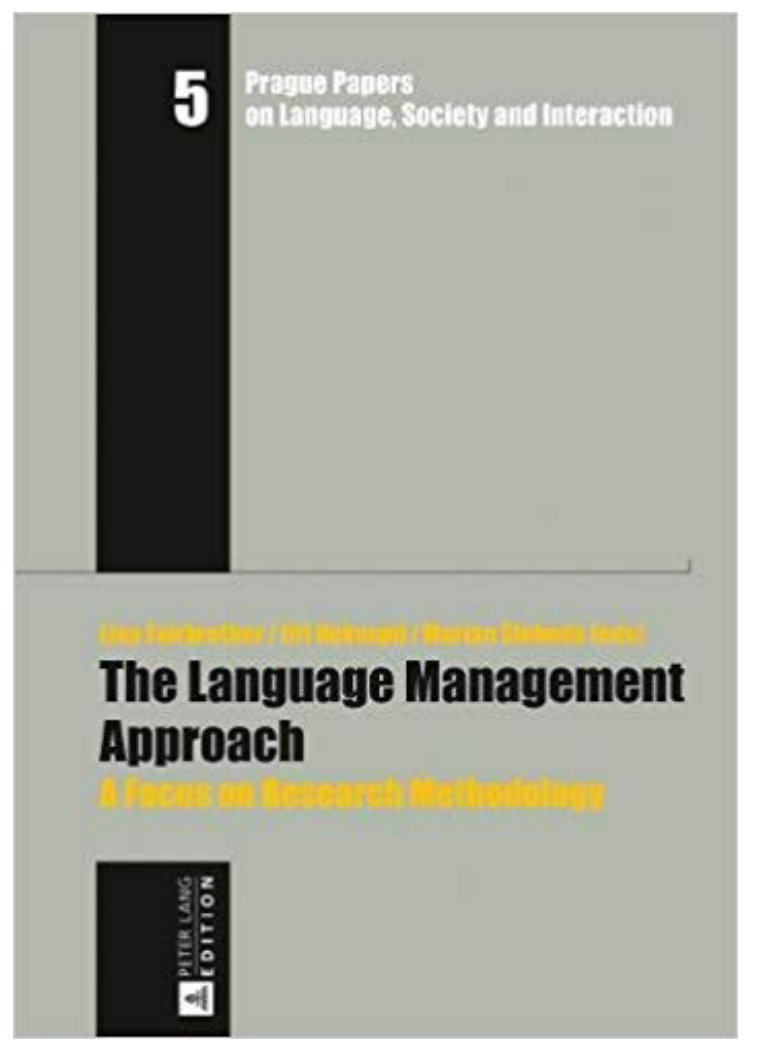

How to cite: Liu, J. 刘景珍 \& Dai M. 戴曼纯. (2020). Book Review of 'The Language Management Approach: A Focus on Research Methodology'. Círculo de Lingüística Aplicada a la Comunicación 82, 255-260, http://dx.doi.org/10.5209/clac.68977

Contents. 1. Introduction. 2. Summary of the Book. 3. Comments. References.

\footnotetext{
${ }^{1}$ Beijing Foreign Studies University 北京外国语大学(China); Jilin University 吉林大学(China). Email: jingzhen@jlu.edu.cn

${ }^{2}$ Corresponding author. Beijing Foreign Studies University 北京外国语大学 (China). Email: daimanchun@bfsu.edu.cn
} 


\section{Introduction}

Language Management Theory (hereafter LMT) was first proposed by Jernudd and Neustupy (1987). It has been one of the most influential theoretical frameworks that have been widely employed from macro-level language policy and planning to micro-level language use in discourse in particular or even to other related fields. The theory originally derived from the research done against the background of language planning studies in the 1960s and 1970s, but now Jernudd and Neustupy have developed this conceptualization into what has become LMT, with its focus shifting from organized management to management of individual conversations (Neustupy, 1973). LMT deals with management procedural acts and activities (such as noting, evaluation) of individual speakers as well as institutions of varying complexity (families, social and political groups, schools, government ministries, media), for the sake of disclosing the relationship between the activities of speakers on the one hand and those of institutions on the other .

The publication of this volume, as is stated by the editors, was inspired by the Third International Language Management Symposium, held at Charles University in Prague in 2013. The themes of the previous two symposiums, one at Monash University (Clayton, Melbourne) in 2008 and the other at Waseda University (Tokyo) in 2011, are "probing of the concept of noting" and "norm diversity and language management in globalized settings" respectively. The main purpose of the third symposium focuses on research methodology, thus this volume provides a description of LMT itself and concentrates on methodology, especially data collection methods.

\section{Summary of the Book}

In the Introduction, Fairbrother, Nekvapil \& Sloboda first outline the themes involved in this volume: "theories of language panning, the application of language policy in universities, the practices of language cultivation agencies and the people who consult them, the use of language in immigrant and multilingual communities, the use of second languages in educational settings(including study abroad), the process underlying literary criticism and attitudes towards different regional language varieties" (p.15-16). Then they move on to offer some background information for research under LMT. It is reaffirmed that language management refers to "the general theory first outlined by Jernudd \& Neustupy (1987)", whereas Spolsky's version of language management is considered as "a domain-focused approach" (Jernudd, 2010; Baldauf, 2012; Nekvapil, 2016). As far as methodology is concerned, LMT has stressed naturally-occurring data. In research, the application of a wide range of methodologies may be identified at different levels of simple management, organized management and connections of simple management and organized management.

Apart from the Introduction and the Epilogue, this volume is composed of four parts. Part I consists of two articles and the aim of this part is linking language management research with other theories. In the first article Baldauf \& Hamid provides an overview of the theoretical and methodological issues in language policy and planning (LPP) by specifying five major directions or schools of thought in this discipline: the classical school; the language management theory school; the domain focused school; the critical studies school and the ethnographic school and the pros and cons of their methodologies. Such a classification and analysis may not be free from controversies but it will surely present a framework, where LMT is placed in relation to other theories in LPP. In the second article, Lanstyak has mainly illustrated the suprastrategies and strategies of managing language problems from a broader perspective. In order to do so, the author makes several sets of important distinctions, among which the most significant is the distinction between D-management (management of particular discourses), Cmanagement (management of circumstances of language use) and I-management (management of ideas, opinions, ideologies concerning languages and language use). These strategies have been identified and summarized based on empirical data of various sources.

In Part II the four studies are concerning the connections between micro- level (simple) and macrolevel (organized) management in the contexts of language management agencies and universities. The first two studies focus on language management issues in language agencies, while the last two are about methods to explore those issues in universities.

In the first study, drawing on the data sets from two Swedish language cultivation agencies, Terminologicentrum TNC and Sprakradet (the Language Council of Sweden), Jernudd analyzes the 
questions from the public and reveals that most of the questions are related to vocabulary and every problem is expected to have only one correct solution from the cultivation agencies. The author also points out that the limited access to the enquirer's management process would not guarantee smooth language problem management. The next article by Benes et al. also investigates the interactions between language users and a language agency (Language Consulting Centre in the Czech Republic) with LMT. They have identified three types of management: pre-interaction management; postinteraction management and interaction management (in-management). In addition, typical enquirers' management stages have been outlined (noting stage; evaluation stage; adjustment design; adjustment implementation and post-implementation feedback) with further elaboration on their respective limits and challenges. Both studies using data sets from language agencies reported similar methodological issues that little access has been gained to the circumstances preceding the enquiry, which might be a complex process and that whether the adjustment design (advice) offered by the agency is actually implemented could not be ascertained.

In the third article of this part, Ali et al. carry out a study on the factors acting on EMI (English as a Medium of Instruction)-related language policies in a Malaysian tertiary institution. In this part of the volume, the authors only discuss one aspect of the main study, that is, how to design interview pro formas based on LMT so as to achieve a spiral effect, which can triangulate findings in different groups of interviewees and make more in-depth examinations of micro-level issues. The last article in this part deals with English-Zulu bilingualism in the University of KwazZulu-Natal. Rudwick investigates the bilingual phenomenon by using a variety of data collection methods: qualitative interviews, focus group discussions and ethnographic observations. The paper reveals that there is a conflict between students' strong recognition of making an African language (Zulu) as a medium of instruction and their reluctance and hesitance to study Zulu themselves, which implies that "the interplay between organized and simple management is only intact on a superficial level"(p.157).

Part III deals with micro-level management and the studies explore simple management from a variety of perspectives. The first article is Aukawa's translation of Neustupny's Japanese paper (Methodology in Japanese studies: the stage of data collection), which presents an overview of methods in Japanese study along the paradigm shifting from early modern to modern and post-modern and then singles out follow-up interviews and interaction interviews as examples of new data collection methodology. The author believes that as paradigm shifts, methodology changes accordingly, thus "new approaches are being created in the contemporary paradigm" (p.197).

Authors of the second and third articles all deal with language management of immigrants. With an ethnographic approach conducted on three immigrants, Muraoka et al. aim at finding out immigrants' language management in contact situations. The ethnographic approach in this paper covers the application of language biography interviews, interaction interviews and the discourse of the interview itself. In contrast, by combining LMT with the concept of personal empowerment, Saruhashi examines an immigrant's language management through participatory observations and a three-phase semistructured interview and finds that personal empowerment through language management (PELM) proves to be effective in revealing the sociolinguistic reality of immigrants and refugees.

The next three articles are all on micro-level language management in the context of language learning. Based on the principles of interaction interview, Fairbrother introduces how to collect related data via emails in a longitudinal study. Email, as a data-eliciting method, does have its disadvantages, but as the author believes that "the value of any methodology depends on what the researcher wants to find out" (p.274) and it is also argued in the article that researchers are supposed to keep an open mind to new possibilities and experiment with new methods (p.276). H. Asada also carries out a longitudinal study on Chinese exchange students' management of their speech styles and speech-style shift in Japanese. This study tries to present the effort of utilizing multiple data collection methods, which is made up of video-recordings of nonnative speaker-native speaker conversations and reciprocal followup interviews. Such a trial is supposed to evoke new directions for introducing reciprocal follow-up interviews to the analysis of naturally occurring interactions. Motivated by Neustupny's paper "Literary Criticism as Language Management", Hromadova's research is an extension of LMT to simple literary criticism. The study compares the similarities and differences in the reading acts of a native and a nonnative of Czech. It is also argued that "the follow-up interview is the most suitable means to explore this process" (p.303). 
Attitudes towards languages or varieties are the focus of the two chapters in Part IV. In the first article, Mrazkova addresses the attitudes of people from two regions in Czech Republic towards the use of Common Czech (a non-standard variety of Czech) on television stations. Her findings reveal that people of distinct varieties react differently to the evaluations of Common Czech and participants' simple management heavily depends on the organized management experienced in their schooling. Re-analysis of the focus group discussion data collected originally for the study of attitudes to language and language ideologies has been conducted by the author for the sake of showing that "whether and how this sort of re-analysis is possible and what the data collected for other purposes could offer to Language Management Theory" (p.330). In the second article, Ozorencik explores family language management of Turkish families in Prague. Semi-interviews and experimental interactions have been used to elicit parental simple management concerning their children's use of Turkish. Data triangulation has also been made by the visit to the children's Turkish Saturday school and interviews with their teachers.

In the Epilogue, the volume ends with Zawiszova's translation of Neustupny's paper published in Japanese in 2004, talking about the historical development of LMT. He has reviewed the relations of LMT to other theories and called for more opening up for synthesis in future research. Most importantly, Neustupny suggests that evolving from Correction Theory to Language Management Theory, it may well deserve to be named by "General Theory of Language Management", since it is "the only system that accommodates both simple and organized management, includes grammatical, non-grammatical communicative and sociocultural management and proposes a processual model” (p.371).

\section{Comments}

\subsection{A Practical Guide to Qualitative Methods in LMT}

Undoubtedly, this volume has made substantial contribution to a systematic introduction to qualitative methodology in LMT research. It provides an overview of the application of a variety of research methods to simple management (micro-level management), organized management (meso-level and macro-level management) and links between organized management and simple management. The interdisciplinary nature of language management has made it possible to share its research methods with fields such as anthropology, sociology, education, linguistics, and political science. Hence a wide range of methods could be applied to language management in various contexts as long as they are fit for the research design and the research questions.

Among all those methods mentioned in the book, two methods that are robust in language management studies are the central focus, namely, the follow-up interview and the interaction interview (p.21). This volume, to some extent, has served as a practical guide to the application of these two methods used in different contexts by presenting detailed explanation and procedures of how to carry them out in papers of Part III, which is the bulk of this book. In addition, multiple data collection methods and triangulation of the data are also emphasized, as can be seen from the studies of Asada, Ozorencik and several others. Furthermore, the use of emails to collect data by Fairbrother and the reanalysis of data by Mrazkova for language management study have been examples of bold trials to challenge traditional research methods and have well accounted for the significance and necessity to embrace an open and dynamic mind in trying out new research methods.

This volume is surely instructive in helping researchers and students in related fields for its readability and applicability. However, as "all the papers in this volume use qualitative research methods" (p.16), it is likely to evoke a belief that quantitative methods may account little in LMT research. In fact, it is not the case. It can be justifiably argued that "data that may be quantitative (including demographic, economic, or census data; test results; questionnaires; and even observations)" (Tollefson, 2015:148) may well act as evidence or at least complementary evidence in LMT research, and quantitative statistical analyses are sometimes of vital help in clarifying and explaining some language phenomena, especially in micro-level language management. Therefore, a comprehensive description of research methodology in LMT is expected to integrate both qualitative and quantitative methods. 


\subsection{Establishment of General Theory of Language Management}

As is stated by Neustupy, only theorization based on both systematization in self-building and connections with other theories can bear "a certain degree of independence" and "stay alive on its own" (p.374). The logical design of this collection has just served to pave the way for the final proposal of updating LMT to General Theory of Language Management in the Epilogue. After defining core constructs of LMT in the Introduction, the editors have selected papers of theoretical significance in Part I to show the linkage of LMT to other theories, in Part II, Part III and Part IV come the main body of papers acting as methodological illustrations in LMT research. Apart from theoretical and methodological considerations, representativeness is also another noticeable feature of this volume. The effort to cover language management on all levels (simple management, organized management and connections between simple management and organized management) can be clearly seen from the display of the contents, and language management problems in various local contexts, from Europe, Africa, Asia to Australasia, are enlisted in this volume. Be it a coincidence or not, research from America, an equally important local context in language management problems, is not traced in this volume, which leaves us room to argue that there is still a step further from a panoramic global view of the research under LMT.

As a future strategy for the development of GTLM, it is proposed to "open up the door to synthesis as far as possible" (p.377). This seems to be a practical and sustainable tactic for long-term development, yet it is quite demanding when such a strategy is applied to resolving problems in practice. For instance, the overlapping use of "language management" in LMT and Spolsky's theory calls for further clarification. In his book Language Management (2009), Spolsky explains his preference for the term "management" over "planning" by the statement "because I think it more precisely captures the nature of the phenomenon" (p.4). Jernudd (2010), in his review article, claims that Spolsky equates language management with language planning and policy (p.83), while Ammon (2010) believes that according to Spolsky's $(2004,2009)$ division of three interrelated components, "language management should deal with a subset of the language problems with which language policy is concerned, as should language policy's other two components: language practice and language beliefs" (p. 197). Besides, Spolsky's theory is also developing and his approach is not simply restricted to domain studies. Spolsky (2004, 2009) also recognizes simple and organized management. And in his latest modification of language policy (and management), he also adds the level of individual management, considering the importance of self-management (Spolsky, 2018). How these issues could be synthesized is yet to be discussed.

In conclusion, this volume has provided not only some useful qualitative research methods for LMT research but also a systematic sketch and a promising blueprint for LMT. It is bound to assist prospective readers in having a better understanding of the interdisciplinary nature of LMT, the methodological openness and its recent developments.

\section{Acknowledgements}

Great thanks go to the editors and anonymous reviewers concerned in the publication of this review. The review is also supported by the Project of "Foreign Language Education Policy in Northeastern Asia and Its Implications for the 'Double First-rate' Construction in Local Higher Education” (吉林省教育厅项 目：东北亚地区外语教育政策研究及其对我省高校 “双一流” 建设的启示 JJKH20190236SK) and the Project of “A Comparative Study of Foreign Language Education Policy in the Northeastern Asian Countries” (吉林大学基础科研业务费项目：东北亚国家外语教育政策的比较研究 2018QY034).

\section{References}

Ammon, U. 2010. Language management. Language Problems \& Language Planning, 34(2), 197-200.

Baldauf, R. B. 2012. Introduction - language planning: Where have we been? Where might we be going? Revista Brasileira de Linguística Aplicada, 12(2), 233-248. DOI: http://dx.doi.org/10.1590/S198463982012000200002.

Fairbrother, L., Nekvapil, J., \& Sloboda, M. (eds.) 2018. The Language Management Approach: A Focus on Research Methodology. Berlin, Bern, Bruxelles, New York, Oxford, Warszawa, Wien: Peter Lang. 
Jernudd, B. H. 2010. Language management. Current Issues in Language Planning, 11(1), 83-89. DOI: https://doi.org/10.1075/lplp.34.2.07amm.

Jernudd, B. \& Neustupný, J. V. 1987. Language planning: For whom? in L. Laforge (ed.), Proceedings of the International Colloquium on Language Planning. Québec: Les Presses de L'Université Laval, 69-84.

Nekvapil, J. 2016. Language Management Theory as one approach in Language Policy and Planning. Current Issues in Language Planning, 17(1), 11-22. DOI: https://doi.org/10.1080/14664208.2016.1108481.

Neustupný, J. V. 1973. An outline of a theory of language problems. Paper prepared for the section Language Planning at the VIII ISA World Congress of Sociology, Toronto, August 16-24, 1974, in J. V. Neustupný, Post-Structural Approaches to Language. Tokyo: University of Tokyo Press, 243-257.

Spolsky, B. 2004. Language Policy. Cambridge: Cambridge University Press.

Spolsky, B. 2009. Language Management. Cambridge: Cambridge University Press.

Spolsky, B. 2018. A modified and enriched theory of language policy (and management). Language Policy, 18(3), 323-338. DOI: https://doi.org/10.1007/s10993-018-9489-z.

Tollefson, J. W. 2015. Historical-structural analysis, in F. M. Hult \& D.C. Johnson (eds.), Research Methods in Language Policy and Planning. Chicester, Sussex, UK: John Willey \& Sons, 140-151. DOI: https://doi.org/10.1002/9781118340349.ch13. 